\title{
The Effect of the Use of Cervical Collar on the Reduction of Neck Pain: Meta-Analysis
}

\author{
Hisyam Syafi'ie'), Hanung Prasetya ${ }^{2)}$, Bhisma Murti1) \\ ${ }^{1)}$ Masters Program in Public Health, Universitas Sebelas Maret \\ 2) Acupuncture Study Program, Health Polytechnic Ministry of Health Surakarta
}

Background: Neck pain is the fourth leading cause of disability, with an annual prevalence rate exceeding 30\%. Nearly 50\% of individuals will continue to experience pain or it often occurs to some degree. This study aimed to analyze the magnitude of the effect of using a cervical collar on reducing the degree of pain in neck pain patients compared to manual therapy (exercises).

Subjects and Method: This research is a systematic review and meta-analysis carried out by following the PRISM diagram flow. The process of searching for articles through a journal database that includes: PubMed, Google Scholar and Science Direct by selecting articles published in 2000-2020. The keywords used include: "cervical collar" OR "neck collar" OR "soft collar" OR "hard collar" AND "neck pain" AND "cervical pain" AND "cervical radiculopathy" AND "cervical syndrome" AND "randomized controlled trial". The inclusion criteria were full paper articles with a randomized controlled trial study design, articles using English and Indonesian, and bivariate analysis with adjusted odds ratio. Articles that meet the require- ments are analyzed using the Revman 5.3 application.

Results: A total of 6 articles were reviewed in this study with a randomized controlled trial study design. Meta-analysis of 6 randomized controlled trial (RCT) studies showed that there was no difference in effectiveness in using cervical collars compared to manual therapy (exercises) in reducing neck pain $(\mathrm{ES}=0.04$; 95\% CI -0.31 to 0.39; $\mathrm{p}=0.083$ ).

Conclusion: This meta-analysis concluded that there was no difference in effectiveness between the use of cervical collars and manual therapy (exercises) in reducing the degree of pain in neck pain.

Keywords: neck pain, cervical collar, exercises,meta-analisis

\section{Correspondence:}

Hisyam Syafi'ie. Masters Program in Public Health, Universitas Sebelas Maret. Jl. Ir. Sutami 36A, Surakarta 57126, Central Java. Email: bunghifi@gmail.com. Mobile: o81326002006.

Cite this as:

Syafi'ie H, Prasetya H, Murti B (2021). The Effect of the Use of Cervical Collar on the Reduction of Neck Pain: Meta-Analysis. Indones J Med. 06(01): 112-118. https://doi.org/10.26911/theijmed.2021.06.01.12.

(c) (i) (2) Indonesian Journal of Medicine is licensed under a Creative Commons EY NC SA Attribution-NonCommercial-ShareAlike 4.o International License.

\section{BACKGROUND}

Neck pain is pain that is felt to appear in the superior area bounded by the superior nuchal line, laterally by the lateral margin of the neck, and inferior by an imaginary transverse line through the $\mathrm{T} 1$ spinous process (Bogduk, 2011). WHO states that neck pain is the fourth leading cause of disability, with an annual prevalence rate exceeding 30\%. Most episodes of acute neck pain will go away with or without treatment, but nearly $50 \%$ of individuals will continue to experience pain or it often occurs to some degree. In general, the prevalence rate of the United States population, 50-70\% will experience neck pain at least once a lifetime, as many as one third affected every year, and about 10\% 
suffer neck pain at some point (Muzin et al, 2007). Neck pain has been associated with poor posture, anxiety and depression, neck strain, work-related injuries, or sports injuries.

The cervical collar is an important orthosis (orthosis) tool and is one of the most popular treatments. A cervical collar is a tool frequently used by physicians and paramedics to stabilize a patient's head and neck to prevent damage to the spine and soft tissue in the neck immediately after a traumatic injury, and then to prevent further damage and improve healing during the days and weeks following the injury.

Several studies have shown that the use of cervical collars of various types and designs can have an effect on reducing the degree of pain in neck pain patients. This is what underlies the author to conduct a systematic review and meta-analysis involving orthotic treatment with the use of a cervical collar to reduce pain in neck pain patients.

\section{SUBJECTS AND METHOD}

\section{Study Design}

This was a meta-analysis research. Article searches were conducted for one month systematically and comprehensively through databases including: PubMed, Google Scholar and Science Direct. Keywords used: "cervical collar" OR "neck collar" OR "soft collar" OR "hard collar" AND "neck pain" AND "cervical pain" AND "cervical radiculopathy" AND "cervical syndrome" AND "randomized controlled trial".

\section{Inclusion Criteria}

The author developed the inclusion criteria, namely a full paper article with a randomized controlled trial (RCT). The intervention given was the use of a cervical collar with manual comparison therapy (exercises). The research subjects were neck pain patients of all ages. The study outcome was pain reduction. Articles are those whose research is conducted all over the world.

\section{Exclusion Criteria}

The exclusion criteria in this study were articles published in languages other than English and Indonesian. The articles are those published under 2000. Observational articles and quasi experiment. The article is not in full text.

\section{Operational Definition of Variables}

The search for articles was carried out by considering the eligibility criteria defined using the PICO model. The population in the study was patients with neck pain of all ages with intervention using a cervical collar comparison, which was given manual therapy (exercises). Outcome was a decrease in the degree of neck pain.

Pain is an unpleasant sensory and emotional experience due to damage to the tissue, either actual or potential or represented in the form of the damage itself. Pain is measured in various size scales, one of which is by using the VAS.

Cervical collar is a type of orthosis that is used for satabilization, immobilization, compensation, and relief of cervical deformities. This orthosis is made with a sponge and plastic material, which aims to provide support and immobilization in the cervical area.

Exercises are movement techniques that are performed to stretch muscles and tendons, which aim to stretch, flex or increase the flexibility of muscles that are considered problematic so as to reduce the restrictions or tension caused by pain.

\section{Data Analysis}

Articles were identified using the PRISMA diagram, and analyzed using the Review Manager 5.3 application by calculating the effect size and heterogeneity to determine which research models were combined to form the final meta-analysis result. 


\section{RESULTS}

The process of reviewing articles can be seen in Figure 1. PRISMA diagram This meta-analysis analyzes 6 primary studies conducted in the Continent of Europe.

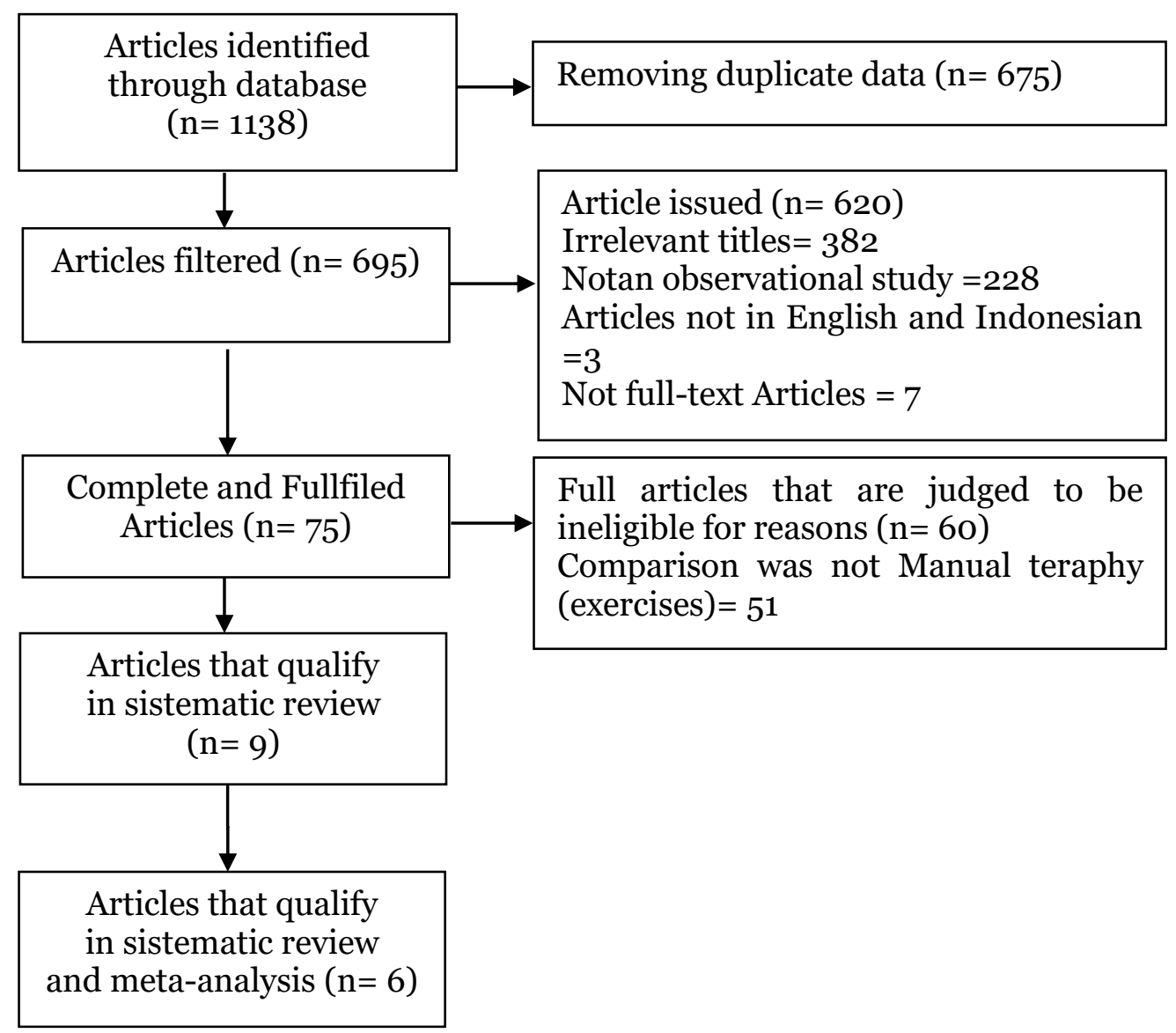

Figure 1. PRISMA diagram

The study quality assessment was carried out quantitatively. This study was conducted using an assessment of the quality of research studies for the design of the Randomized controlled Trial (RCT)
Center for Evidence Based Management (CEBMa) and the cross sectional Center for Evidence Based Management (CEBMa) in 2014. 
Syafi'ie et al./ The Effect of the Use of Cervical Collar on the Reduction of Neck Pain

Table 1. Assessment of the quality of the randomized controlled trial study

\begin{tabular}{|c|c|c|c|c|c|c|c|c|c|c|c|c|c|}
\hline \multirow{2}{*}{ Primary Study } & \multicolumn{13}{|c|}{ Criteria } \\
\hline & $\mathbf{1}$ & 2 & 3 & 4 & 5 & 6 & 7 & 8 & 9 & 10 & 11 & 12 & Total \\
\hline Kujiper et al. (2009) & 1 & 1 & 1 & 1 & 1 & 1 & 1 & 1 & 1 & 1 & 0 & 1 & 11 \\
\hline Persson et al. (2001) & 1 & 1 & 1 & 1 & 1 & 1 & 1 & 1 & 1 & 1 & $\mathrm{O}$ & 1 & 11 \\
\hline Schnabel et al. (2004). & 1 & 1 & 1 & 1 & 1 & 1 & 1 & 1 & 1 & 1 & $\mathrm{O}$ & 1 & 11 \\
\hline Bonk et al. (2000). & 1 & 1 & 1 & 1 & 1 & 1 & 1 & 1 & 1 & 1 & $\mathrm{O}$ & 1 & 11 \\
\hline Rosenfeld et al. (2003) & 1 & 1 & 1 & 1 & 1 & 1 & 1 & 1 & 1 & 1 & o & 1 & 11 \\
\hline Vassiliouet al. (2003) & 1 & 1 & 1 & 1 & 1 & 1 & 1 & 1 & 1 & 1 & o & 1 & 11 \\
\hline
\end{tabular}

Table 2. Descriptions of primary studies included in the meta-analysis

\begin{tabular}{|c|c|c|c|c|c|c|c|}
\hline $\begin{array}{l}\text { Author } \\
\text { (year) }\end{array}$ & Country & $\begin{array}{c}\text { Study } \\
\text { Design } \\
\end{array}$ & Sample & $\mathbf{P}$ & I & $\mathbf{C}$ & $\mathbf{O}$ \\
\hline $\begin{array}{l}\text { Kujiper et } \\
\text { al. (2009) }\end{array}$ & Netherlands & $\begin{array}{l}\text { Randomized } \\
\text { Controlled } \\
\text { Trial. }\end{array}$ & $\begin{array}{l}\text { Cervical } \\
\text { collar: } 69 \\
\text { Excercises: } \\
70 \\
\text { Total: } 139\end{array}$ & $\begin{array}{l}\text { Neck } \\
\text { pain }\end{array}$ & $\begin{array}{l}\text { Using a } \\
\text { cervical } \\
\text { collar }\end{array}$ & $\begin{array}{l}\text { Perform } \\
\text { manual } \\
\text { therapy } \\
\text { treatment } \\
\text { (excercises) }\end{array}$ & $\begin{array}{l}\text { Reduction } \\
\text { in degree of } \\
\text { pain }\end{array}$ \\
\hline $\begin{array}{l}\text { Perssonet } \\
\text { al. (2001) }\end{array}$ & Sweden & $\begin{array}{l}\text { Randomized } \\
\text { Controlled } \\
\text { Trial. }\end{array}$ & $\begin{array}{l}\text { Cervical } \\
\text { collar: } 27 \\
\text { Excercises: } \\
27 \\
\text { Total: } 54\end{array}$ & $\begin{array}{l}\text { Neck } \\
\text { pain }\end{array}$ & $\begin{array}{l}\text { Using a } \\
\text { cervical } \\
\text { collar }\end{array}$ & $\begin{array}{l}\text { Perform } \\
\text { manual } \\
\text { therapy } \\
\text { treatment } \\
\text { (excercises) }\end{array}$ & $\begin{array}{l}\text { Reduction } \\
\text { in degree of } \\
\text { pain }\end{array}$ \\
\hline $\begin{array}{l}\text { Schnabel } \\
\text { et al. } \\
(2004)\end{array}$ & Germany & $\begin{array}{l}\text { Randomized } \\
\text { Controlled } \\
\text { Trial. }\end{array}$ & $\begin{array}{l}\text { Cervical } \\
\text { collar: } \\
97 \\
\text { Excercises: } \\
\text { 103 } \\
\text { Total: } 200\end{array}$ & $\begin{array}{l}\text { Neck } \\
\text { pain }\end{array}$ & $\begin{array}{l}\text { Using a } \\
\text { cervical } \\
\text { collar }\end{array}$ & $\begin{array}{l}\text { Perform } \\
\text { manual } \\
\text { therapy } \\
\text { treatment } \\
\text { (excercises) }\end{array}$ & $\begin{array}{l}\text { Reduction } \\
\text { in degree of } \\
\text { pain }\end{array}$ \\
\hline $\begin{array}{l}\text { Bonk et al. } \\
(2000)\end{array}$ & Denmark & $\begin{array}{l}\text { Randomized } \\
\text { Controlled } \\
\text { Trial. }\end{array}$ & $\begin{array}{l}\text { Cervical } \\
\text { collar: } 50 \\
\text { Excercises: } \\
47 \\
\text { Total: } 97\end{array}$ & $\begin{array}{l}\text { Neck } \\
\text { pain }\end{array}$ & $\begin{array}{l}\text { Using a } \\
\text { cervical } \\
\text { collar }\end{array}$ & $\begin{array}{l}\text { Perform } \\
\text { manual } \\
\text { therapy } \\
\text { treatment } \\
\text { (excercises) }\end{array}$ & $\begin{array}{l}\text { Reduction } \\
\text { in degree of } \\
\text { pain }\end{array}$ \\
\hline $\begin{array}{l}\text { Rosenfeld } \\
\text { et al. } \\
(2003)\end{array}$ & Sweden & $\begin{array}{l}\text { Randomized } \\
\text { Controlled } \\
\text { Trial. }\end{array}$ & $\begin{array}{l}\text { Cervical } \\
\text { collar: } 23 \\
\text { Excercises: } \\
21 \\
\text { Total: } 44\end{array}$ & $\begin{array}{l}\text { Neck } \\
\text { pain }\end{array}$ & $\begin{array}{l}\text { Using a } \\
\text { cervical } \\
\text { collar }\end{array}$ & $\begin{array}{l}\text { Perform } \\
\text { manual } \\
\text { therapy } \\
\text { treatment } \\
\text { (excercises) }\end{array}$ & $\begin{array}{l}\text { Reduction } \\
\text { in degree of } \\
\text { pain }\end{array}$ \\
\hline $\begin{array}{l}\text { Vassiliouet } \\
\text { al (2006) }\end{array}$ & Germany & $\begin{array}{l}\text { Randomized } \\
\text { Controlled } \\
\text { Trial. }\end{array}$ & $\begin{array}{l}\text { Cervical } \\
\text { collar: } 97 \\
\text { Excercises: } \\
103 \\
\text { Total: } 200\end{array}$ & $\begin{array}{l}\text { Neck } \\
\text { pain }\end{array}$ & $\begin{array}{l}\text { Using a } \\
\text { cervical } \\
\text { collar }\end{array}$ & $\begin{array}{l}\text { Perform } \\
\text { manual } \\
\text { therapy } \\
\text { treatment } \\
\text { (exercises ) }\end{array}$ & $\begin{array}{l}\text { Reduction } \\
\text { in degree of } \\
\text { pain }\end{array}$ \\
\hline
\end{tabular}


Syafi'ie et al./ The Effect of the Use of Cervical Collar on the Reduction of Neck Pain

\section{a. Forest plot}

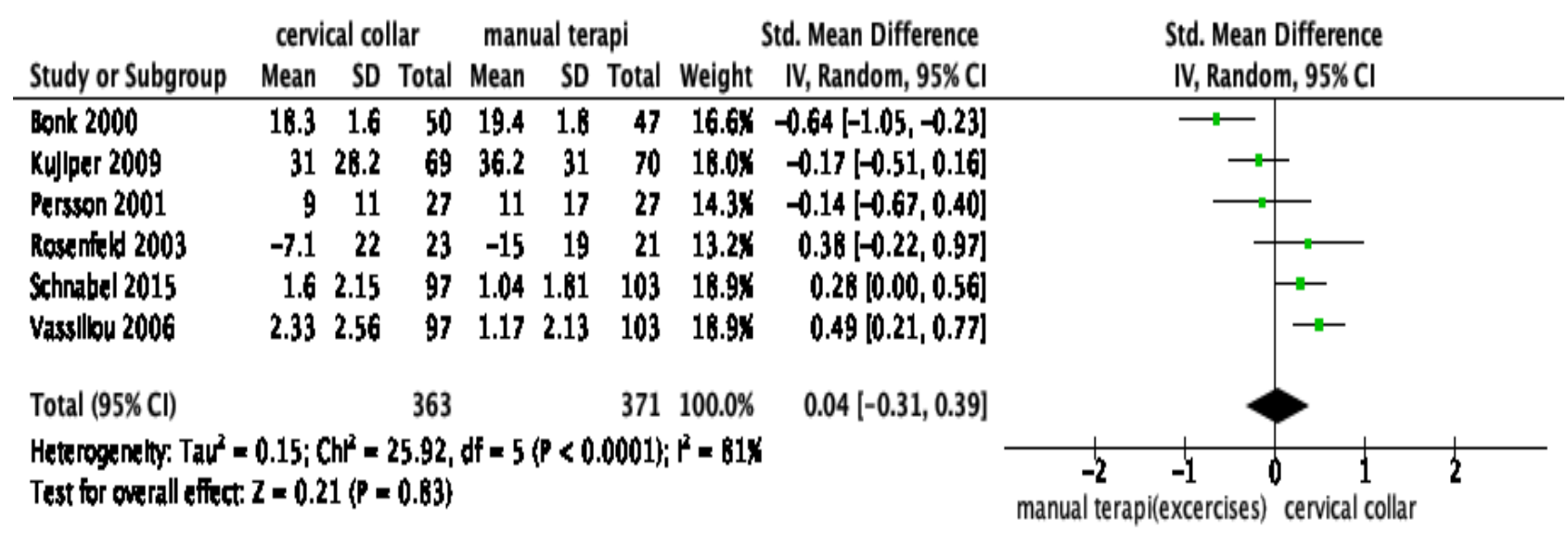

Figure 2. Forest plot of the effect of cervical collar use to reduce the degree of pain in neck pain.

Forest plot Figure 2 shows that cervical collar is not different in reducing pain level in neck pain patients compared to manual therapy (exercises) with 95\% CI $=-0.31^{-}$ 0.39 and it is not statistically significant as evidenced by $\mathrm{p}<0.001$. The heterogeneity of the research data shows $\mathrm{I}^{2}=81 \%$ so that the distribution of the data is stated to be heterogeneous (random effect model).

The funnel plot in Figure 3 shows that there is no publication bias due to the symmetrical distribution of the plot. The plot on the left of the graph has a standard error between 0.2 and 0.3 and the plot on the right has a standard error between 0.1 and 0.3 .

\section{b. Funnel plot}

Figure 3. shows that there is no publication bias due to the symmetrical plot distribution.

\section{c. Funnel Plot}

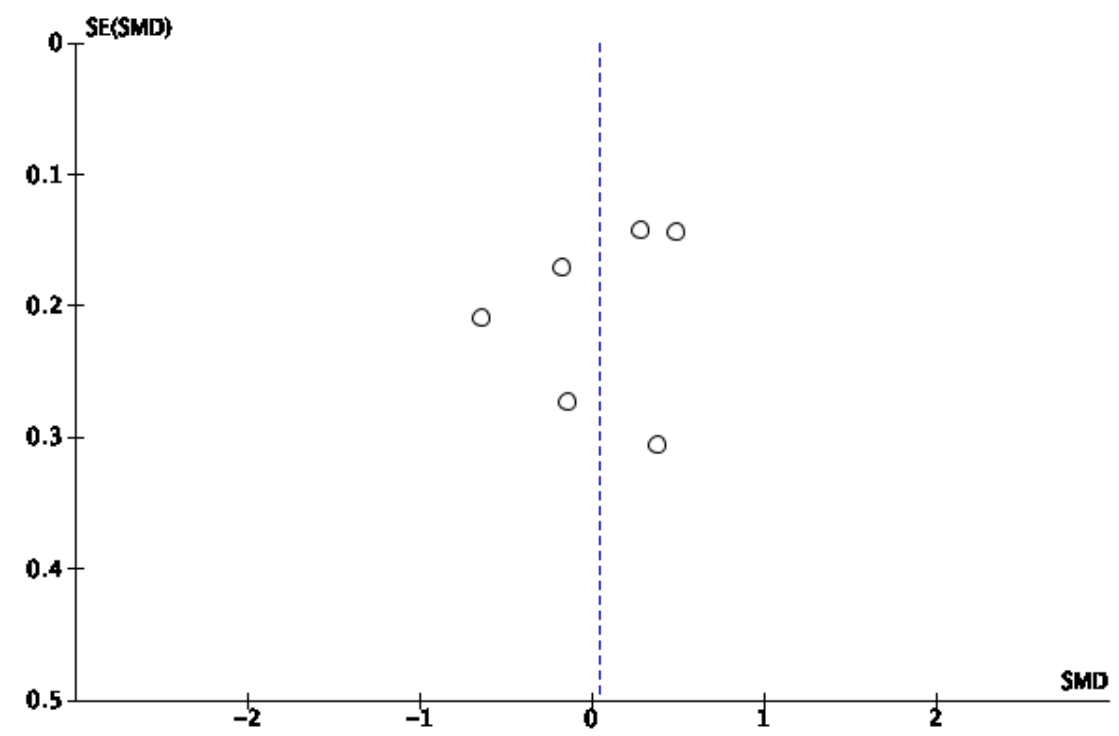

Figure 3. Funnel plot of the effect of cervical collar use to reduce the degree of pain in neck pain 


\section{DISCUSSION}

This systematic review and meta-analysis study took the topic of the effect of using cervical collars on reducing the degree of pain in neck pain. The factor used as an independent variable in this study was using a cervical collar. The outcome which became the dependent variable in this study was a decrease in the degree of pain in neck pain. This study aims to determine the magnitude of the effect of using a cervical collar on reducing the degree of pain in neck pain.

Articles that have been compiled through database searches are then entered into Mendeley's program to make identification easier. The initial search process yielded 1138 articles, after the process of deleting published articles (data from more than one database), 675 articles were obtained. A total of 695 articles were excluded because the title was irrelevant $(n=382)$, not full text $(n=7)$, the article was not in English $(n=3)$, the study design was not an RCT $(n=228)$. The remaining 75 of them meet the requirements for further full text review. Of the 75 full text articles, a total of 65 articles were excluded because the comparisons of the studies did not match the applied criteria $(n=50)$.

Then obtained 6 articles that meet the quantitative requirements for a meta-analysis of the effect of using a cervical collar on reducing the degree of pain in neck pain patients.

The quality of 6 articles was selected using the 2014 CEBMa Critical Assessment Checklist for case-control and cross-sectional studies specifically. Primary articles that have met the requirements are then analyzed using the Review Manager 5.3 program.

This study related to the effect of the use of cervical collars on reducing the degree of pain in neck pain patients con- sisted of 6 articles from Europe, 2 studies from Germany, 2 studies from Sweden, 1 study from Denmark, 1 study from the Netherlands.

The results of the meta-analysis process can be seen through the forest flot. Figure 2 shows that cervical collars did not differ in reducing the degree of pain in patients with neck pain compared with manual therapy (exercises) $(p=0.083)$. The heterogeneity of the research data shows I2 $=81 \%$ so that the distribution of the data is stated to be heterogeneous (random effect model).

The results of the data analysis are in line with Ricciardi et al. (2019), which states that the use of cervical collars in patients with neck pain can reduce the degree of pain and however, manual therapy protocols (exercises) show better pain relief. on neck pain. This study is in line with the research conducted by Thoomas et al., (2013) which states that both interventions, namely cervical collar and manual therapy (exercises), can significantly reduce the degree of pain in neck pain patients.

So it can be concluded that there is no statistically significant difference in the effectiveness of using cervical collars compared to manual therapy (exercises) in reducing neck pain.

\section{AUTHOR CONTRIBUTION}

Hisyam Syafi'ie is the principal researcher who selects topics that explore and collect research data. Hanung Prasetya and Bhisma Murti played a role in analyzing data and reviewing research documents.

\section{CONFLICT OF INTEREST}

There is no conflict of interest in this study.

\section{FUNDING AND SPONSORSHIP}

This study is self-funded. 
Syafi'ie et al./ The Effect of the Use of Cervical Collar on the Reduction of Neck Pain

\section{ACKNOWLEDGEMENT}

We are grateful to the database providers PubMed, Google Scholar and Science Direct.

\section{REFERENCE}

Binder AI (2008). Neck pain. BMJ Clin Evid. http://www.ncbi.nlm.nih.gov/pmc/articles/pmc2907992/.

Bogduk N (2011). The anatomy and pathophysiology of neck pain. Phys Med Rehabil Clin N Am. 22(3): 367-382. https://doi.org/10.1016/j.pmr.2011.0 3.008 .

Briggs AM, Woolf AD, Dreinhöfer K, Homb N, Hoy DG, Kopansky-Giles D, Åkesson K, March L (2018). Reducing the global burden of musculoskeletal conditions. Bull World Health Organ. 96(5): 366-368. https://doi.org/10.2471/BLT.17.204891.

Genebra C, Maciel NM, Bento T, Simeão S, Vitta A (2017). Prevalence and factors associated with neck pain: a population-based study. Braz J Phys Ther. 21(4): 274-280. https://doi.org/10.1016/j.bjpt.2017.05.005.

Hurwitz EL, Morgenstern H, Harber P, Kominski GF, Yu F, Adams AH (2002). A randomized trial of chiropractic manipulation and mobilization for patients with neck pain: clinical outcomes from the UCLA neckpain study. Am J Public Health, 92 (10): 1634-1641. https://doi.org/10.2105/ajph.92.10.1634.

Murti B (2018). Prinsip dan metode riset epidemiologi. Edisi V. Karanganyar: Bintang fajar Offset.

Muzin S, Isaac Z, Walker J, Abd OE, Baima $J$ (2008). When should a cervical collar be used to treat neck pain?.
Curr Rev Musculoskelet Med. 1(2): 114-119. https://doi.org/10.1007/s12178-007-9017-9.

Persson LC, Lilja A (2001). Pain, coping, emotional state and physical function in patients with chronic radicular neck pain. A comparison between patients treated with surgery, physiotherapy or neck collar--a blinded, prospective randomized study. Disabil Rehabil Assist Technol. 23(8): 325335. https://doi.org/10.1080/09638280010005567.

Ricciardi L, Stifano V, D'Arrigo S, Polli FM, Olivi A, Sturiale CL (2019). The role of non-rigid cervical collar in pain relief and functional restoration after whiplash injury: a systematic review and a pooled analysis of randomized controlled trials. Eur Spine J. 28(8): 1821-182. https://doi.org/10.1007/s00586-019-06035-9.

Schnabel M, Ferrari R, Vassiliou T, Kaluza $G$ (2004). Randomised, controlled outcome study of active mobilisation compared with collar therapy for whiplash injury. Emerg Med J. 21(3): 306-310. https://doi.org/10.1136/emj.2003.010165.

Strine TW, Hootman JM (2007). US national prevalence and correlates of low back and neck pain among adults. Arthritis Rheum. 57(4): 656-665. https://doi.org/10.1002/art.22684.

Thoomes EJ, Scholten-Peeters W, Koes B, Falla D, Verhagen AP (2013). The effectiveness of conservative treatment for patients with cervical radiculopathy: A systematic review. Clin J Pain. 29(12): 1073-1086. doi: 10.1097/AJP.obo13e31828441fb. 